\title{
Amazonia: the last surviving Amazonian indigenous languages
}

\author{
Ademar dos Santos Lima ${ }^{1}$ \\ Antonio Augusto Souza Mello ${ }^{2}$ \\ Rosineide Magalhães de Sousa ${ }^{3}$
}

\begin{abstract}
In this article, we present the last surviving Amazonian indigenous languages after more than four centuries of colonization in Brazilian Amazonia. To expand the study, we divided the languages into five categories: alive, extinct, dead, weakened and revitalized. The methodologies used were the quali-quanti approach and ethnographic and descriptive research. The techniques employed were meta-research with a focus on bibliographic data and field study. The study found that of the 495 indigenous languages of Brazilian Amazonia, only 27 still survive and are spoken fluently, 265 have become extinct, 3 are dead and have only written records, 195 are weakened and are spoken by people over 40 and 5 have been revitalized and reintroduced into the practice of interaction and communication in the linguistic community. We also approach the concept of each of these categories of indigenous languages and the situation in which each language is within the context of these language categories.
\end{abstract}

Keywords: Amazonian languages; indigenous people; endangered languages; dead and extinct languages.

\section{Initial considerations}

The first reports on linguistics contact with the indigenous peoples of the Amazonia are found in texts (letters) by western navigators from the 16th, 17th and 18th centuries of the colonial period in the Amazon region. These documents describe in a detailed and detailed way the geographical, environmental, cultural and linguistic characteristics of the Amazonia and its people.

The letters written by Carvajal (1541) Relación del Descubrimiento del Río de las Amazonas; Acunã (1637), New Discovery of the Great Amazon River; Fritz (1686) The diary of Father Samuel Fritz; La Condamine (1745) Travel in South America down the Amazon River; Noronha (1768) Travel itinerary from Pará to the last colonies of the hinterland; Heriarte, (1874) Description of the State of Maranhão, Pará, Corupá and Rio das Amazonas, and La Espada, (1889) Viaje del capitán Pedro Texeira, waters up the rio de las Amazonas:

1. Professor and researcher in Nheengatu indigenous language in Amazonia and $\mathrm{PhD}$ student in linguistics at the University of Brasília (UnB).

2. PhD in Linguistics from the Federal University of Santa Catarina (2000) and post-doctorate from the Federal University of Santa Catarina (2015). He is currently Adjunct Professor III at the University of Brasilia. Has experience in Linguistics with emphasis on Historical Linguistics.

3. Associate professor at the University of Brasília. She works in the Degree in Rural Education in the Linguistics Area, and in the Post-Graduation in Linguistics - line of research "Language, Sociocultural Interaction and Literacy. She is Leader of the Research Group (Socio) Linguistics, Multiple Literacies and Literacy, certified by CNPq. 
1638-1639 are our logbook to investigate the last surviving Amazonian languages from the comparison of linguistic data of these texts with those of today.

In order to understand the term Amazonian languages, we must also observe the terms Amazonian countries and Amazonian linguistic borders, given that all of these terms are intrinsically linked to the context of the Amazonia, since the Etymology of this toponym appears during the expedition of Francisco de Orellana in 1540 and 1542 when he descended the Amazonas River in all its extension, starting from the Andes and who in his reports claimed to have seen women warriors that he called them Amazonas. Since that time, the river was renamed the Amazonas River from which the term Amazonia was derived (BESSA FREIRE, 1983).

According to Queixalós and Renault-Lescure (2000) there are three more acceptable variables in the classification process of Amazonian languages. The first would be to consider all those languages that are within the Amazonian biome that is in the geographical space of the Legal Amazonia. The second variable would be based on philological connections between languages, and the third variable would be to consider as Amazonian languages those that belong to the linguistics and protolanguage families that originated or had as a point of dispersion from Amazonia.

When we referring to Amazonian languages today, we observe that the linguistics panorama of the Amazon region is characterized by the predominance of three language families widely dispersed in the geographical space of the Amazonian biome, encompassing the so-called Amazonian countries such as: Bolivia, Brazil, Colombia, Ecuador, Guyana, French Guiana, Peru, Suriname and Venezuela which are Aruák, Karíb and Tupi-Guarani linguistics families. Of course, currently we also find languages of the Macro-Jê linguistics family in the Amazonia, mainly in the state of Rondônia, due to the migratory flow of the Jê peoples in the 17th, 18th, 19th and 20th centuries (QUEIXALÓS; RENAULT-LESCURE, 2000).

The number of language families counted in the Amazonia is 52 families and in each language family the number of languages varies from one to forty. In total, the number of indigenous Amazonian languages still considered alive today is approximately 227 languages, also including the dialects. (QUEIXALÓS; RENAULT-LESCURE, 2000).

The first demographic census of the indigenous population in the Amazonia or part of it was through a survey and sampling survey applied by D'abbeville (1614, p. 221-222) at the island of Maranhão and surrounding lands which in its coexistence with the people Tupinambá from Maranhão and Pará, he found through demographic census that in each hollow (house) 
there were about 80 indigenous people residing and that this was common in the villages he visited throughout that immense geographical area. Thus, he made a demographic estimate of the population of that region in the early 17 th century.

Noronha (1945) used this same survey technique not only to check the population demography in the villages along the Amazonas River and its tributaries, Tapajós and Madeira, but also to quantify the number of languages in the first half of the 18th century. The projections of estimates reached were that there were 495 languages in the beginning of colonization in the Amazonia. But if we take into account the indigenous languages of the Amazonian countries and of gentile $e^{1}$, indigenous people estimates indicate that there were approximately 700 indigenous Amazonian languages in the 16th century. However, in this study we consider only the languages of the Brazilian Amazonian biome.

We observed that in the sixteenth century there was no information from these researchers on the number of language families existing in the Amazonia, nor were they taken into account in these linguistics surveys of the languages of the Gentile peoples that today we call isolated peoples. But in this work, we consider both the languages of the Gentile peoples and those of the isolated Amazonian peoples, because it is interesting to know how many Amazonian languages actually existed in the Brazilian Amazonia, so that we can from that totality make a brief survey of how many languages were extinct, dead and how many still survive only at the Brazilian side.

Thus, we believe that the documents produced in the colonial period in the Amazonia are true dossiers on the region's riches, from economically viable plants known as hinterland drugs, fauna such as fish, turtles and wild animals and especially of Amazonian populations and languages that our focus of study in these writings.

It is undoubtedly relevant to talk about Amazonian fauna and flora and the study of the geography and history of the region as all of these come together to conceive in the Amazon region a mosaic of varied and multilingual linguistics situations and it is without doubt a landmark for the Linguistics Sciences because the history of the Amazonian indigenous languages is the history of the cultural devastation caused by the colonizers of a universe of 495 languages that were spoken before the arrival of Westerners in the Amazonia (RODRIGUES, 2007).

\footnotetext{
1 The term gentile indigenous was used by the colonizers of the 16th, 17th, 18th and 19th centuries and referred to the unknown indigenous people who were not subject to the colonizer. In the twentieth century, Fundação Nacional do Índio (FUNAI) changed its name to uncontacted indigenous peoples as isolated indigenous people, referring specifically to indigenous groups with no permanent relationship with national societies.
} 
For this reason, we dedicate ourselves to the sociolinguistic issues of the indigenous peoples of the Amazonia and their languages, and to better organize this article, we divided the study of Amazonian languages into five categories: live languages, extinct languages, dead languages, debilitated languages and revitalized languages.

Indigenous languages today are considered to be wealth and immaterial heritage of Brazilian society. However, it was not always so. On the occasion of the arrival of Europeans in Brazil, more specifically in the Amazonia in the 16th, 17th and 18th centuries there were several attempts to silence indigenous peoples, including forbidding them to speak their mother tongues as was the case with the Directory of Indians decree (1758) by Sebastião José de Carvalho e Melo, the Marquis of Pombal who prohibited the teaching and practice of any indigenous language in the Amazonia in that time (COELHO, 2016).

If the impacts that this law had on indigenous languages were not enough, other problems such as diseases brought by these colonizers and wars decimated hundreds and thousands of speakers of Amazonian languages and, obviously their languages perished along with them. Languages that had not been registered yet (COELHO, 2016).

In the view of the colonizers, indigenous languages always represented a state problem for them and committed to conquering the Amazon territory in the colonial period, they tried to provide for the extinction of these languages using the role of religion and the Portuguese language in the background preaching and confession of indigenous people. Thus, in the eighteenth century there was a more drastic accent in which evangelization for the purpose itself, definitively loses its role as protagonist submitting itself to the political and economic integration of the State and thus, they arise to the ideas of universalization of the Portuguese language from the Portuguese Royal Crown (OUEIXALES; RENAULT-LESCURE, 2000).

Thus, it was decreed the extermination of the Amazonian indigenous languages which were so numerous and diverse that according to the calculations of the linguists, they estimated that there were approximately 1,200 indigenous languages in Brazil and of these hundreds of languages, 700 were spoken in the Amazonia including those of the indigenous gentile peoples (RODRIGUES, 2007).

We believe that the extinction of these indigenous languages as imposed by European colonists not only created chaos in the way of social communication, but also in the way in which indigenous peoples elaborated, codified and preserved their knowledge of the world. 
Thus, we seek to show in this work that after four centuries of colonization practiced by westerners in Brazilian Amazonia few indigenous languages remain alive or revitalized among dozens that have been extinct, dead or are in a state of weakness.

The article is structured based on the Summary which brings brief considerations about the results of the study; this initial considerations which provides a brief overview of the discussions proposed in the development of the work; Section 2, which deals with the methodological procedures, methods and techniques of the research; Section 3, which discusses the concepts and distinguishes between living, extinct, dead, debilitated, revitalized languages and presents quantitative data on the status of those languages and; finally, Section 4, we makes the final considerations and points out possible future studies.

\section{Methodological procedures}

The study of the last surviving Amazonian indigenous languages in its initial phase consisted of readings corresponding to the literature review of the subject addressed based on letters from the colonial period in Amazonia by Carvajal (1541), Acunã (1637), Fritz (1686), La Condamine (1745), Noronha (1768), Heriarte, (1874) and La Espada, (1889).

The conception of scientific research spread mainly in the 19th century in the midst of the positivist movement of Auguste Comte (1798-1857) in response to metaphysical traditions used until then to explain natural and social life phenomena. The main contributions of the positivists are to outline rigorous assumptions to explain the logic of natural phenomena by the exact sciences and a posteriori of social phenomena by the human and social sciences (Cf. LOBATO, 1986; BORTONI-RICARDO, 2008).

Thus, scientific knowledge is acquired empirically from what can be sensorially experienced. Thus, acceptable explanations are those based on facts with a focus on knowable objects.

In this sense, when dealing with issues of human matter especially verbal language, the researcher is not a passive reporter, but an active agent and the relationship with his research object. Therefore, must be situated and considered in the analysis of the facts investigated (BORTONI-RICARDO, 2008, p. 32). 
Thus, we established an alternative model that favored the investigation of linguistics meanings that cannot be inferred only from the logical correlation of cause or consequence and data quantification. Thus, this epistemology used by various disciplines in the humanities has led us to a qualitative bias that fell on the linguistics investigation that we conducted here through the qualitative approach. Although, quantitative data were also collected and evaluated for the interpretation and construction of analyzes and conclusions.

\subsection{Methods}

Generally, the methods are confused with methodology and methodology with the research design. However, methods are procedures used to collect data used as a basis for inference and interpretation for explanation and prevention whereas methodology describes and analyzes these methods showing their limitations and resources, clarifying their assumptions and consequences and relating their potentialities in the transition from frontiers of scientific knowledge (PAIVA, 2019, p. 15).

Thus, a research method refers to a technology for conducting a scientific study. That is a tool and technique for doing research with the purpose of discovering new information or better understanding the object of study.

Thus, in this study we use ethnography, field research and survey survey that are common in linguistics studies and widely used to collect and describe linguistics characteristics, attitudes, views, opinions and so on from language speakers and other types of people that is important for the study. (PAIVA, 2019, p. 50).

\subsection{Scope of the investigation}

The investigation had a range of descriptive study involving documentary, bibliographic studies and field research aiming at the "description of the categories and classification of the situation of the Amazonian languages and the establishment of relationships between the variables". In the case of this study, we deal with the situation of indigenous Amazonian languages in: live languages, weakened languages, extinct languages, dead languages and revitalized languages (GIL, 2006, p. 73).

\subsection{Universe and sample}


To research the status of the last surviving Amazonian indigenous languages, we have classified them all into five categories: live languages, weakened languages, extinct languages, dead languages and revitalized languages. We consider indigenous languages from the Brazilian Legal Amazon biome as research universe.

\subsection{The data collection path}

Initially, we carried out a bibliographic survey of texts from the colonial period which are the letters written by Carvajal (1541), Acunã (1637), Fritz (1686), La Condamine (1745), Noronha (1768), Heriarte, (1874) and La Sword, (1889). These documents contain detailed information about the geography peoples and languages of the Amazon region at the time of colonization in the Amazonia. Based on detailed readings, we separated the names of the peoples and languages mentioned in these documents including those indigenous groups that the writers of that period called "Gentile Indians" and which currently the National Indian Foundation (FUNAI) calls them "isolated indigenous people", because they are people who do not have contact and they do not know their names or what languages they speak.

After the collection of information in these old documents of names and languages of indigenous peoples, we began to collect information also in the most current linguistics texts on indigenous Amazonian languages in the works of Rodrigues (2005); Queixalos and RenaultLescure, (2000); Bessa Freire (2003); Brazilian Institute of Geography and Statistics (IBGE, 2010) and FUNAI (2017). Finally, we conducted an ethnographic study in the indigenous communities of Amazonas to verify the languages that are in the process of revitalization.

\subsection{Data analysis technique}

The study was divided into three phases. In the first phase, we made a list with the names of all the peoples and languages mentioned in the letters from the colonial period including Gentile peoples. Then, we organized a second list with all the languages recently cited by linguists Rodrigues (2005), Queixalos and Renault-Lescure (2000), Bessa Freire (2003), IBGE (2010) and FUNAI (2017) also including the languages of isolated peoples cited by the National Indian Foundation.

In the second phase of the study, we separated languages by category of live languages, weakened languages, extinct languages, dead languages and revitalized languages. To find out 
the status of each language and to classify it into one of these categories, we analyzed the latest research records on the languages that are still spoken and compared them with the languages on the list of texts by the colonial period to see which ones were on current list and, thus, we separate those that are alive from those that are weakened and those that are weakened from those that are extinct from those that are dead and from those that are revitalized. In the case of the languages of the Gentile peoples, we rely on the number of times of quotations that the writers made in each river they visited and claimed to have found groups of Gentile Indians in that location. Thus, that group was supposed to speak a language. In the case of isolated indigenous people today it was the same procedure, based on the National Indian Foundation (FUNAI) report (2017) which mentions that there are 67 isolated indigenous peoples in the Amazon, and we consider that each group speaks a language adding up to 67 languages. In this way, we quantify and classify the Amazonian languages within each category.

In the third phase of the study, we elaborated a table with five subdivisions and in each one we listed the languages by category in alive, debilitated, extinct, dead and revitalized languages and later we produced a graph with the total number of languages by categories and total general described in item 3.6 classification data of Amazonian languages by categories.

\section{The conception of alive, extinct, dead, debilitated and revitalized language}

The understanding of concept in the area of Linguistics seeks to clarify in a reflexive way the conceptual terms, since these elements are presented as nuclear and are interrelated in their structures and establish semantic relations among themselves for better understanding and cognitive reflection of the subject addressed (DAHLBERG, 1992); (FERRATER-MORA, 2004).

In this way, we believe that as the concept is a knowable object and it manifests itself as a phenomenon that is understood by the subject and whose function is shaped by a given dialectic context.

For Almeida (2005) the language can be classified as alive, dead or extinct. However, we realize that currently the conception of this author does not account for a more precise classification, since the sociolinguistics studies of the last fifteen years point for two more types of fundamental concepts in the research of these phenomena which are weakened and revitalized languages (CALVET, 2002).

Therefore, in this chapter we first discussed the concept of linguistics classification in 
alive, debilitated, extinct, killed and revitalized or recovered languages and then we analyzed the differences between these terms, and finally we classified the languages by each category.

\subsection{Live Language}

The concept of live language is related to time, space and its use in the social context that it is alive, because language is being used in various sociocultural contexts and in various communicative and interaction situations between people who speak it and that use like a product of a practice (CALVET, 2002, p. 134).

For Bakhtin (2006, p. 270) language has life because it is a continuous dialogue between social subjects that is it is in constant use by its speakers in both oral practice, in writing and in reading.

We can say, then, that the live language is characterized as one that is used as a means of continuous communication and interaction between individuals of a certain linguistics community (COSTA, 1996).

As examples of live indigenous languages, we mention Tikúna which has over 35 thousand speakers, Guarani Kaiowá with over 30 thousand speakers and Nheengatu with approximately 20 thousand speakers among others (IBGE, 2010).

However, for Ethnologue (2020) all Brazilian indigenous languages are in risk of extinction and this phenomenon is not exclusive to minority languages in Brazil, but also to minority languages in the world where 2,5 thousand of these languages are in danger disappear.

We know that languages through the linguistics contact of the people who speak them, who write them and who listen to them every day have the ability to survive various natural climatic phenomena, but when their speakers die or are subjected to other cultures and languages hegemonic, their languages also tend to disappear or evolve into a new linguistic variety, that even, so presents itself as a problem of social communication (CALVET, 2002, P. 43).

Therefore, live languages especially minority languages that are spoken by an ethnic minority or minorities that are in a political and social situation with discredited languages are more likely to disappear.

\subsection{Extinct language}

The term extinct language is said to have no more speakers and the language has not 
been registered, that is, it is a language that even before its phonological construction was constituted (grammatized), its speakers died or lost the ability to speak in that language ( VIOTTI, 2008); (VIARO, 2013).

Minority languages are suffocated by majority languages just as majorized languages suffocate minorized languages and the result can be the extinction of these less prestigious languages if they have not yet gone through the phonological construction process and their speakers cease to exist or speak these languages (Harrison, 2011, p. 399).

In this way, a language in the minority or minority situation can disappear in just a few decades without leaving any traces or fragments. This was what happened in the 16th century with the languages Manáu and Tarumã of the Arawk linguistic family in which both the peoples and these languages were extinguished without even wanting to register some words. Hence the expression left no root or branch that is the root represented the speakers and the branch the language (MALAQUIAS, 2008, p.439)

The extinction of a language involves several factors from negative State actions on the language, loss of territory or forced changes to the traditional culture of the people who speak it, falling into disuse or obsolescence, negative attitudes and linguistic behavior of speakers (CALVET, 2002, p. 133).

The concept of extinct language is different from dead language, because while the term extinct language refers to the language that disappeared without leaving a record and its speakers were also extinct or no longer used that language as a means of communication, the dead language for example, in turn, it is the one that has phonological and grammatical records, but has fallen into disuse by its speakers that is the language is no longer used (VILAS BOAS \& HUNHOFF, 2014).

Once the language is extinct there is no way to recover or revitalize it, since the dead language by having phonological and grammatical records can be revitalized as long as there are communities of speakers interested in learning or relearning the dead language (HARRISON , 2011).

The state of life for death and death for life and resurrection is a recurring discussion in the Sciences of Religion and Bioethics and for linguistics, it is something even more plausible, since the language even after being considered dead can be revitalized or recovered (LUCAS, 2008); (COHEN, 1995).

Therefore, there is just no more solution for the extinct language, as this, in addition to having no more speakers there is also no evidence of its existence (ALMEIDA, 2005, p. 18).

The language extinction process can be classified into three types, the first being 
sudden extinction which occurs when there is a sudden loss of a complete group of speakers; the second type is the radical extinction that is similar to the first case, however, there are still some survivors who, little by little abandon their language because they no longer have anyone to interact with and communicate with; and finally the type of gradual extinction that is the most common and may take decades until there are no more speakers and no records of that language (JONES, 2003).

\subsection{Dead language}

The concept of dead language differs from the term extinct language, since the dead word for Linguistics means that there are no more speakers, but the language is phonologically registered and has a grammar. So that if there is an interested group they can revitalize the language in a social context of socio-communicative interaction (HERRISON, 2011

Thus, from the grammar and vocabulary (lexicon) of the language already known and recorded in written documents or in media the language can be revitalized and thus be reintroduced into the social and cultural context of the linguistic group or community.

The death of a language is similar to the process of extinction, however, a language even after death there is still the possibility of being revitalized, recovered, while the extinction is definitive.

When we speak of dead languages we usually think of Latin and we forget the dozens of indigenous languages that died or were extinct in Amazonia. And if we analyze carefully we will notice that Latin does not even fit into this category of dead languages, but in the category of weakened language. Not only because Latin has phonological and grammatical records, but also because it is still spoken in the Vatican, used in the Eucharistic mass liturgies of the priests of the Roman Catholic church, use by people in the area of law in their instances and especially in the faculties of the courses of Law and Letters.

\subsection{Weakened language}

The concept of weakened language falls on the fact that it is in danger of disappearing and cannot be classified either as an extinct language or as a dead language because in turn, it is marked by the fact that it is in a situation of languor and no longer be used in a colloquial or social way, but only in ritual situations. From the point of view of the socio-international context language has lost its value as a means of communication and timidly is used in rites, 
mainly religious and cultural and by older people in bilingual linguistic communities. (CRISTÓFARO-SILVA, 2002).

In other words, the weakened language means that it is in a situation of disuse and the speakers who practice oral or written in that language gradually stop practicing it in the group's socio-cultural context. Thus, we can say that the weakened language is in the process of transition from alive to death or even extinction.

In this sense, the language in a weakened situation goes through the process of linguistic deficit in which the speakers lose their language skills and competences at the same time that the language falls into disuse (BAGNO, 2017, p. 79).

It is a state that can also be called a hypothetical language as we do not know exactly what can happen with the weakened language as there are three possibilities: it can be revitalized, or evolve to death or extinction (VIARO, 2013).

In this way, the language that is alive goes into a state of weakness and from this situation of weakness it can evolve into a state of dead language or extinct language. As an example of a weakened language we can use Latin that passed from the state of live language, used in the social context, in various sociocultural contexts and in various communicative and interaction situations for restricted use in certain rites in religious and religious environments in academic and legal spaces.

Therefore, the language before entering the debilitated stage, that is, losing its vitality as a living language state, it can pass through five levels, stages in decreasing form from a stage of live and safe language to that of insecure, from threatened to severely threatened until in the last stage of critically threatened and from there evolve to the stage of weakened language.

\section{5. Revitalized language}

The concept of revitalized language or linguistic revitalization also known as linguistic recovery is an attempt to prevent or reverse the decline of a weakened language or to prevent its death or extinction and even to recover a language that has already died (CALVET , 2007).

The term revitalization or linguistic recovery is controversial in studies of the literature of language contacts. And that depends on the area of interest of researchers in Linguistics, Sociology, Anthropology, among others. The interpretations vary and thus, the revitalization can be understood as a set of actions to rescue the vitality of a language in a weakened or dead state (CRYSTAL, 2005, p. 58).

Thus, the act of revitalizing a weakened or dead language emerges as an alternative 
intervention in a situation in which the minority language has lost its place as a language of communicative interaction with the majority language and, thus, seeks to strengthen it in a preventive way, before it disappears from the sociolinguistic coexistence of its speakers (CALVET, 2002, p. 138).

In this sense, our relativistic view of linguistic revitalization is not restricted to the term resurrecting a dead language, but rather to strengthen it, that is, to revitalize it. So, these revitalization actions need to be built based jointly with the linguistic community (in vivo) (CALVET, 2002, p. 133).

In this way, linguistic revitalization does not only consist of inserting a minority indigenous language in regular education based on national state or municipal legislation, but also presupposes a series of guidelines in planning and linguistic attitudes and in the sociolinguistic awareness decisions of the social use of language by community members as well as strengthening socio-cultural practices (ALTENHOFEN, 2013).

Thus, we understand that policies to revitalize indigenous minority languages need to be monitored and guided jointly between a close partnership with the educational entities of Indigenous School Education and the leaders and teachers of the linguistic communities where these languages in situations of weakness are spoken.

\subsection{Classification data of Amazonian languages for categories}

Table 1. Category and concept of Amazonian languages

\section{CATEGORY}

Live Language

Extinct language

Dead language

Weakened language

Languages revitalized

\section{CONCEPT}

Daily communication language used in sociocultural contexts and in various situations interactions of communicative practices between the people who speak it. Language that no longer has any speakers and neither phonological or grammatical records.

Language that has phonological and grammatical records, but no more speakers.

Language spoken by a minority group and only among the elderly, in liturgies and religious rituals.

It is the recovery of a language from a weakened or dead state to a state of living language.

The term live language when we refer to Amazonian indigenous languages has a different connotation than when we refer to modern languages given that indigenous language, even though they are considered live languages. To UNESCO all Amazonian indigenous languages are in risk of disappearing, due to exactly the phenomenon of sociolinguistic displacement that speakers of these minority languages suffer at the expense of the expansion 
of dominant or majority languages and actions on these minority languages.

There is a classification presented by Crystal (2000, p. 20) in live languages that have a population base large enough to guarantee a probable existence in the long term; viable but small languages that have more than 1,000 speakers and that are spoken in isolated communities or with a large internal organization who are aware of their language as a mark of their identity; endangered languages that are spoken by a sufficient number of people to guarantee their survival, but only in favorable circumstances and with the growth of their community support; almost extinct languages that are almost beyond the possibility of survival, usually being spoken by only a few elderly people; and extinct languages that are the ones that your last fluent speaker died and there is no sign of revitalization.

These classifications proposed by Crystal (2005) seem to be a little complex and confusing as only a macro reality is discussed, but it fails to show the reality of languages that are already extinct or without any speakers and still gives the possibility of revitalizing those languages, even after the death of the last speakers of these extinct languages. It points out that indigenous languages that have a large population base can remain for a long time without being threatened with extinction when in fact all indigenous languages are in risk of disappearing according to UNESCO. For this reason, we created a more precise and didactic reclassification in order to facilitate the understanding and clarity on the part of the reader about these categories of indigenous languages in Board 1, where we list all the indigenous Amazonian languages described in the texts of the colonial period as well as the languages cited in the most recent works by linguists by category, classification and by the names of languages or peoples. 
Board 1. List of Brazilian Amazonian languages by categories

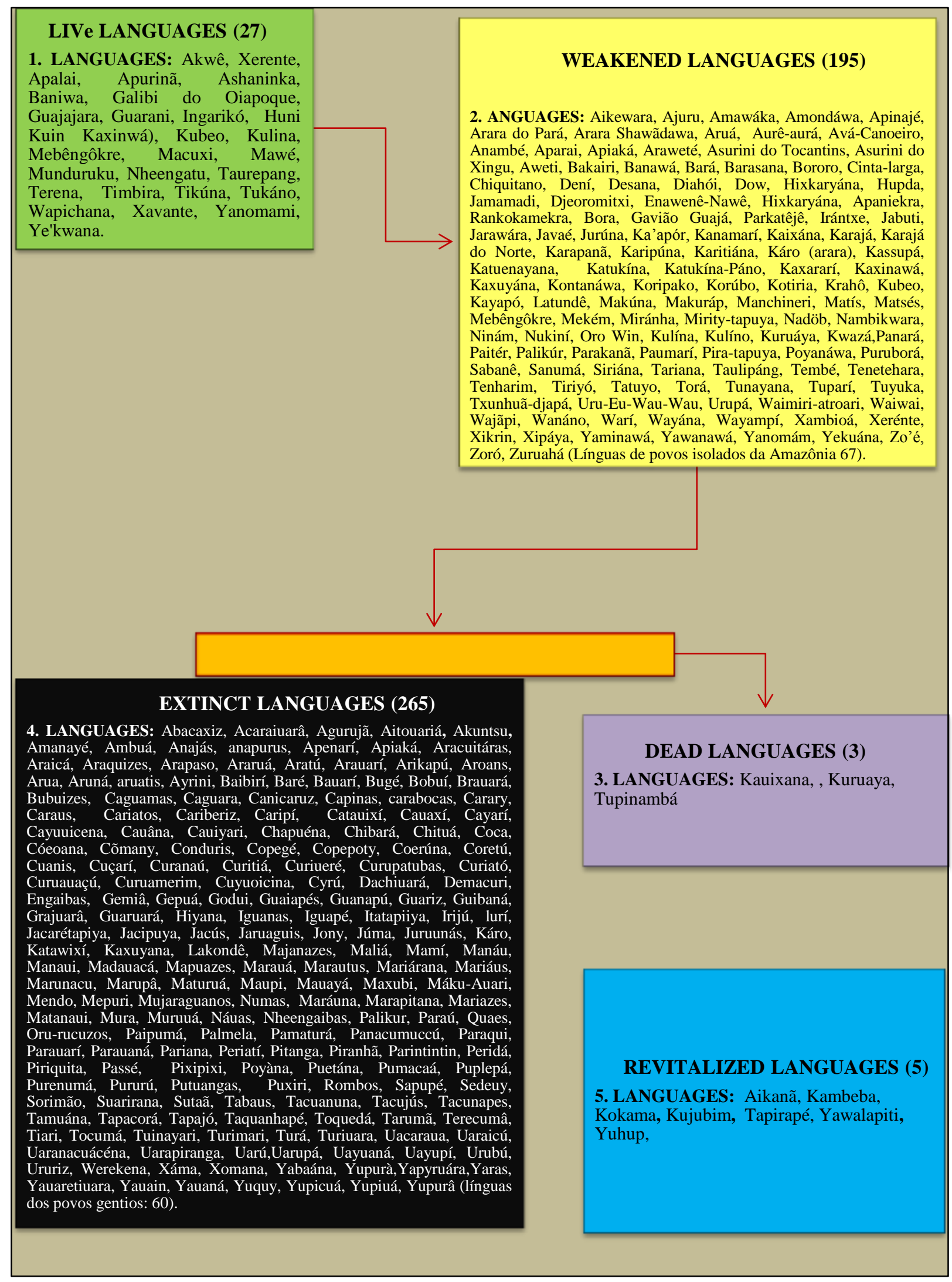


As shown in the list of Amazonian languages by categories in Board 1, we note that the current situation of these languages is very critical as UNESCO has already warned which states that all Brazilian indigenous languages are in risk of disappearing.

In the results of this study, we see that of the 495 indigenous Amazonian languages that existed in the beginning of the 16th century, 265 were extinct, that is $53 \%$ of those languages disappeared forever. Another 195 are debilitated that is $39 \%$ of these languages are heading towards death or extinction if nothing is done. Another 3 languages are dead, however, they can still be revitalized, and 5 languages that were dead have been revitalized that represent only $1.01 \%$ from this universe of 495 languages. Currently, only 27 Amazonian languages are considered to be alive, the people speak fluently and have over 5,000 speakers.

Languages in a debilitated situation have between 2 speakers to 5 thousand speakers and in the language communities where these languages are a vehicle for communication, usually only the elderly over 40 years old and the youngest only understand, but not speak. This is a sign that little by little indigenous languages are no longer spoken and are heading towards death or extinction as we have seen in our research described here.

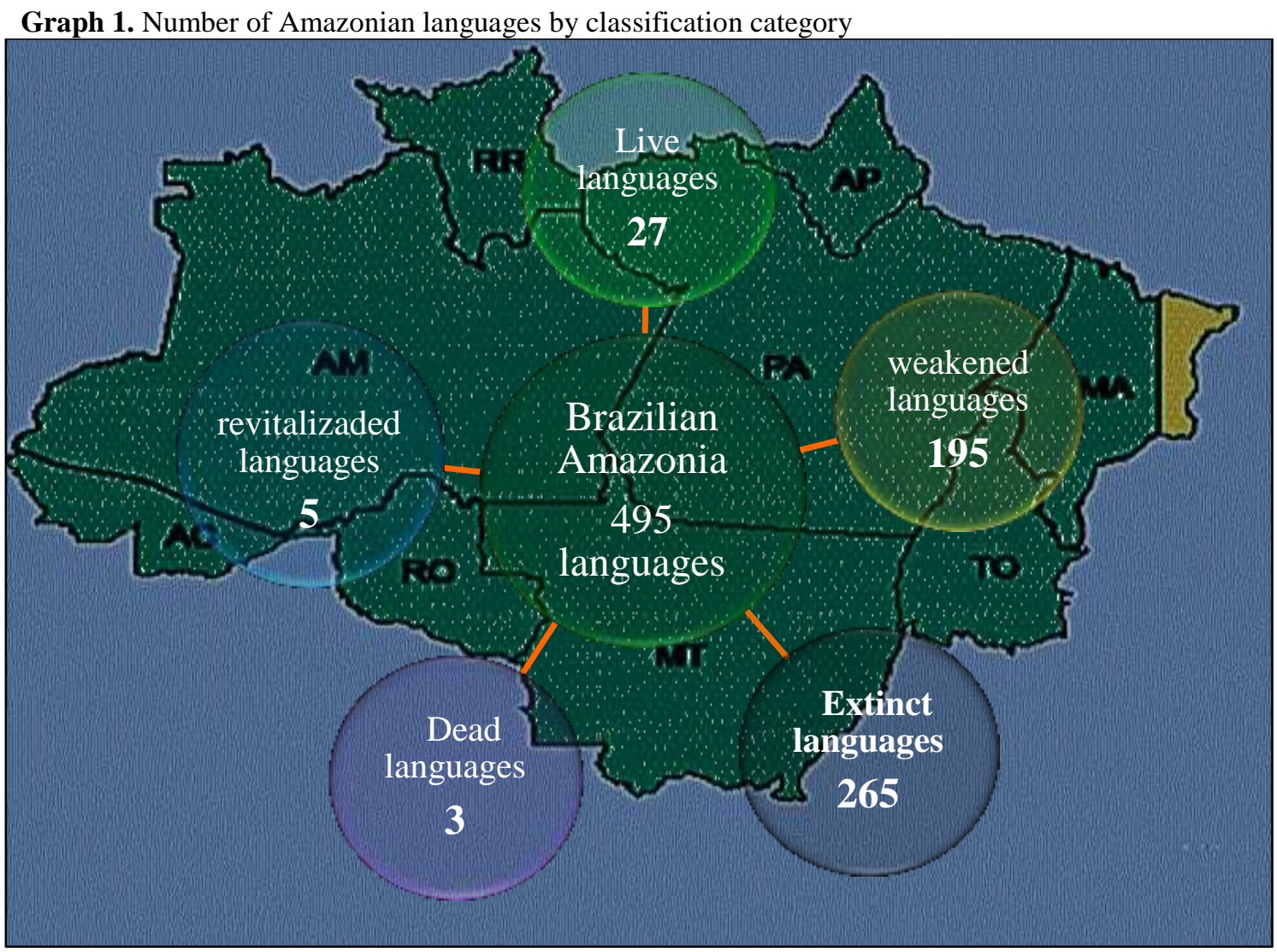

In Graph 1, we diagram the numbers of Amazonian languages by category in each 
circle. In the light green circle the 27 live languages, in the yellow circle the 195 weakened languages, in the light blue circle the 5 revitalized languages, in the purple circle the 3 dead languages, in the black circle the 265 extinct languages and in the leaf green large centralized circle the totality of languages that existed in the beginning of colonization in the Brazilian Amazonia in the 16th century.

The circles in green, yellow, blue, purple and black symbolize the situation in which the languages find themselves. Green symbolizes live and fluently spoken languages, yellow symbolizes weakened languages spoken by a few speakers and over 40 years old, purple symbolizes dead languages that no longer have only a written part, black symbolizes extinct languages that do not it has more speakers and no written part and the large leaf-green circle symbolizes the Amazon biome where languages are located in the beginning of colonization in the Brazilian Amazonia in the 16th century.

\section{Final considerations}

Language is not only a means of communication and interaction, but also a cultural element of identifying a people. It works as a conducting link for the expression of the human being's identity and it also works as a bridge that connects speakers from the past, present and future and, thus, it allows the speaker to find knowledge of the world and human experience, so necessary to a continuous effort to prevent languages from disappearing.

In this way, language policies and positive actions on indigenous languages are fundamental to enhance the process of revitalizing and strengthening minority languages in the Amazonia. Thus, the sociolinguistic contact as well as the nature of the relationship between the inhabitants and the social character of the contact and the purpose of the interaction need to be stimulated in the sociocultural context of the speakers.

The attitudes, values and sociolinguistic knowledge of the speakers are essential to maintain the interaction between groups with their peers and with those of other cultures without losing the local linguistic identity. The minority linguistic community needs to understand how sociolinguistic factors can act in favor of maintaining the minority language and make the social and linguistic situation in contact environments always conducive to the engagement and maintenance of multilingualism.

The heterogeneity of languages in the world is already represented by a few speakers and these very few representativities need to have a voice in their own minority languages making these speakers stop using majority languages in environments that can exercise their local 
languages, transferring all their practices social and cultural resources for their languages.

The current situation is worrying, since of a total of 495 indigenous Amazonian languages that existed in the beginning of the 16th century in the Brazilian Amazonia, 265 languages were extinct in just 400 years and another 195 languages may not last more than three decades. Thus, there is an urgent need for joint efforts to develop linguistic policies and positive actions on these indigenous minority Amazonian languages so that the culture and linguistic diversity in the Amazonia can continue to alive as the 27 Amazonian indigenous languages that still survive and using by indigenous people in their social context.

\section{References}

Acunã, Christóbal Diatristán de (1641). Nuevo descubrimiento del gran rio de las Amazonas. Madrid: Imprenta del Reyno.

Almeida, Napoleão Mendes de (2005). Gramática metódica da língua portuguesa. 45. ed. São Paulo: Saraiva.

Altenhofen, Cléo V (2013). Rumos e perspectivas das políticas linguísticas para línguas minoritárias no Brasil: entre a perda e o inventário de línguas. In: Farenzena, Nalú (org.). Atas do VI Encontro Internacional de Investigadores de Políticas Linguísticas. Porto Alegre: UFRGS. pp. 19-26.

BAGNO, Marcos (2017). Dicionário crítico de sociolinguística. São Paulo: Parábola.

Bakhtin, Mikhail (2006). Estética da criação verbal. Trad. Paulo Bezerra. 4 ed. São Paulo: Martins Fontes.

Benchimol, Samuel (1999). Amazônia: formação social e cultural. Manaus: Valer.

Bessa Freire, José Ribamar (2003). Da língua geral ao português: para uma história dos usos sociais das línguas na Amazônia. 2003. 239f. Tese (Doutorado em Literatura Comparada), Universidade Estadual do Rio de Janeiro, Rio de Janeiro, RJ.

Bessa Freire, José Ribamar (2004). Rio Babel: a história das línguas na Amazônia. Rio de Janeiro: Atlântica.

Bessa Freire, José Ribamar (1983). Da "fala boa" ao português na Amazônia brasileira. Ameríndia, n. 6, pp. 39-83.

Bíblia, A. T. Malaquias (2008). In: Bíblia. Sagrada Bíblia Católica: Antigo e Novo Testamento. Tradução: José Simão. São Paulo: Sociedade Bíblica de Aparecida. p. 439.

Bortoni-Ricardo, Stella Maris (2008). O professor pesquisador: introdução à pesquisa qualitativa. São Paulo: Parábola. 
Brasil; Ministério da Justiça (2017). Povos Indígenas Isolados e de Recente Contato. Brasília: Fundação Nacional do Índio (FUNAI).

Calvet, Louis-Jean (2007). As políticas linguísticas. São Paulo: Parábola editorial; IPOL.

Calvet, Louis-Jean (2002). Sociolinguística: uma introdução crítica. (Trad. de Marcos Marcionilo). São Paulo: Parábola Editorial.

Carvajal, Frei, Gaspar de (1941). Descobrimentos do Rio das Amazonas (1541). Tradução, C. de Melo-Leitão. São Paulo: Companhia Editora Nacional.

Cohen, Claudio; SEGRE, Marco (2008). Bioética. 3. Ed. São Paulo: Faculdade de Medicina, USP.

Coelho, Mauro Cezar (2016). Do sertão para o mar: um estudo sobre a experiência portuguesa na América, o caso do Diretório dos Índios (1750-1798). São Paulo: Editora Livraria da Física.

Colombo, Cristovão (1984). Diários de descoberta da América: as quatro viagens e o testamento; tradução Milton Persson. São Paulo: L\&PM Pocket.

Costa, Francisco Vanderlei Ferreira da (2013). Revitalização e ensino de língua indígena: interação entre sociedade e gramática. [Tese de Doutorado]. Programa de Pós-Graduação em Linguística e Língua Portuguesa da Faculdade de Ciências e Letras. São Paulo: Unesp Araraquara.

Costa, Vera Lúcia Anunciação (1996). A importância do conhecimento da variação linguística. Educar em Revista, Curitiba, vol. 12, pp. 51-59.

Cristófaro-silva, Thais (2002). Morte de língua ou mudança linguística? - Uma revisão bibliográfica. Revista do Museu Antropológico - UFG. Goiás, vol. 5-6, n. 1, pp. 55-73.

Crystal, David (2005). A revolução da linguagem. Tradução, Quintana, Ricardo. Rio de Janeiro: Jorge Zahar.

Crystal, David (2000). Language death. United Kingdom: Cambrigde University Press.

Dahlberg, I (1992). Knowledge organization and Terminology: phisolophical and linguistic bases. International Classification, Frankfurt, v. 19, n. 2, pp. 65-71.

D’abbeville, Pe (1975). Claudio. História da Missão dos Padres Capuchinhos na Ilha do Maranhão e terras circunvizinhas (1614). Tradução Cesar Augusto Marques. Belo Horizonte: Itatiaia/EDUSP. p. 297.

Ethnologue (2020). Languages of the World. Twenty-third edition. Dallas, Texas: SIL International.

Ferrater-Mora, J (2004). Dicionário de filosofia. 2. ed. São Paulo: Loyola. 
Fishman, J. A (1972). Language in Sociocultural Change. Stanford: Stanford University Press.

Fishman, J. A (1972). Language Maintenance and Language Shift as fields of Inquiry. In Linguistics, n 9. pp. 77-133.

Fishman, J. A (1996). Language revitalization. In: Goebel, Hans. et al. (eds.). Contact linguistics: an international handbook of contemporary research. Handbooks of linguistics and communication science. Berlin: Walter de Gruyter \& Co.

Fishman, J. A (1967). Bilingualism with and without diglossia; diglossia with and without bilingualism. In: Journal of Social Issues, n. 23. pp.29-38.

Fritz, Pe. Samuel (2017). Journal of the Travels and Labours of Father Samuel Fritz in the River of the Amazons between 1686 and 1723. [Issued for 1922]. London: Cambridge University Press.

Gil, Antônio Carlos (2006). Métodos e técnicas de pesquisa social. 6. Ed. São Paulo: Atlas.

Heriarte, Mauricio de (1874). Descripção do Estado do Maranhão, Pará, Corupá e Rio das Amazonas, feita por Mauricio de Heriarte, Ouvidor-Geral, Provedor-Mór e Auditor, que foi, pelo Governador D. Pedro de Mello, no Anno de 1662 [Description of the state of Maranhão, Pará, Corupá and Rio das Amazonas]. Vienna.

Herrison, David K (2011). When languages die: The extinction of the world's languages and the erosion of human knowledge. Department of Linguistics. University of Massachusetts Amherst, 226. South College. Language, Volume 87, № 2.

Instituto Brasileiro de Geografia e Estatística (2012). Censo Brasileiro de 2010. Rio de Janeiro: IBGE.

Instituto de Investigação e Desenvolvimento em Política Linguística (2020). A diversidade linguística como patrimônio cultural. Brasil: IPOL.

Instituto de Investigação e Desenvolvimento em Política Linguística (2015). Leis e línguas no Brasil: o processo da cooficialização e suas potencialidades. Florianópolis: IPOL.

Jobim, Anísio (1957). O Amazonas e sua história: ensaio antropogeográfico e político. São Paulo: Companhia Editora Nacional.

Jones, Meirion Prys (2003). As línguas ameaçadas de extinção e a diversidade linguística na União Europeia. Direção-Geral das Políticas Internas.

La condamine, Charles-Marie de (1945). Relation abrégée d'un voyage fait dans l'intérieur de 'Amérique méridionale. Depuis la côte de la mer du Sud, jusqu'aux côtes du Brésil \& de la Guiane, en descendant la riviere des Amazones; lûe à l'assemblée publique de l'Académie des Sciences, le 28 avril 1745. Paris: Veuve Pissot.

La espada, Marcos Jimenez de (1889). Viaje del capitán Pedro Texeira aguas arriba del rio de las Amazonas: I638-I639. Madrid I m p r e n t a de Fortanet calle de la Libertad: Mindlin. 
Lima, Ademar dos Santos (2016). Educação escolar indígena: um estudo sociolinguístico do nheengatu na escola Puranga Pisasú do rio Negro, Manaus, AM. Dissertação (Mestrado em Letras e Artes) - Universidade do Estado do Amazonas (UEA), Manaus, Amazonas.

Lobato, Lúcia Maria Pinheiro (1986). Sintaxe gerativa do Português: da teoria padrão a teoria da regência e ligação. Belo Horizonte: Vigilia. p. 558.

Lucas, Ramón (2008). Explícame la bioética: Guía explicativa de los temas más controvertidos sobre la vida humana. Madrid, Espanha: Ediciones Palabra.

Maher, Terezinha de J. M (2010). Políticas linguísticas e políticas de identidade: currículo e representações de professores indígenas na Amazônia ocidental brasileira. Currículo sem Fronteiras, v.10, n.1, pp. 33-48.

Martins, Marlúcia Bonifácio; Oliveira, Tadeu Gomes de Oliveira (Org.) (2011). Amazônia Maranhense: Diversidade e Conservação. Belém: Museu Paraense Emílio Goeldi (MPEG).

Metraux, Alfred (1948). Handbook of South American Indians: The Tupinamba. V. 3. Washington 25, D. C.

Noronha, José Monteiro de (1862). Roteiro da Viagem da Cidade do Pará até as últimas colônias do Sertão da Província (1768). Pará: Typographia de Santos \& Irmãos.

Paiva, Vera Lúcia Menezes de Oliveira e (2019). Manual de pesquisa em estudos linguísticos. São Paulo: Parábola.

Papavero, Nelson et al (1999). A fauna da Amazônia brasileira nos relatos de viajantes e cronistas dos séculos XVI ao XVIII: a descrição do estado do Maranhão, Pará, Corupá e Rio das Amazonas de Mauricio de Heriarte (1662). Rio de Janeiro: Universidade Federal Rural do Rio de Janeiro.

Queixalos, Francisco; Renault-Lescure, Odile [org.] (2000). As Iínguas amazônicas hoje. Las lenguas amazônicas; HoyLes langues d'Amazonie aujourd'hui; The Amazonian languages today. São Paulo: Instituto Socioambiental.

Ramirez, Henri (2006). As línguas indígenas do Alto Madeira: estatuto atual e bibliografia básica. Língua Viva - Versão eletrônica - Volume 01, nº 01.

Rodrigues, Aryon D (2007). A ameaça à diversidade linguística no Brasil. Conferência realizada no âmbito dos Seminários do LALI, Universidade de Brasília.

Rodrigues, Aryon D (2005). Evidências linguísticas da antiguidade do piolho e de outros parasitas do homem na Amazônia. Brasília: Revista de Estudos e Pesquisas.

Rodrigues, Aryon D (1993). Línguas indígenas: 500 anos de descobertas e perdas. São Paulo: D.E.L.T.A. 9: pp. 83-103.

Rodrigues, Aryon D (2000). Panorama das Línguas Indígenas da Amazônia. Em: F. Queixalós \& Renault-Lescure (orgs): As línguas amazônicas hoje. São Paulo, IRD/ISA/MPEG, 
pp. 15-28.

United Nations Educational, Scientific and Cultural Organization (2020). Interactive Atlas of the World's Languages in Danger, UNESCO.

Viaro, Mário Eduardo (2013). Manual de etimologia do português. 2. ed. São Paulo: Globo Livros.

Vilas boas, Cristiane Max Serra; Hunhoff, Elizete Dall'Comune (2014). Um estudo sobre a origem da língua portuguesa: do latim à contemporaneidade, contexto poético social. Revista Moinhos, v. IV, pp. 33-45.

Viotti, Evani de Carvalho (2008). Introdução aos estudos linguísticos. Florianópolis: Universidade Federal de Santa Catarina (UFSC). 